\section{Cellular Physiology} and Biochemistry Published online: November 13, 2015

Accepted: October 21, 2015

\title{
Stimulation of Eryptosis by Narasin
}

\author{
Ghada Bouguerraa,b Rosi Bissinger ${ }^{a}$ Salem Abbès ${ }^{b}$ Florian Lang ${ }^{a}$ \\ aDepartment of Physiology, University of Tübingen, Tübingen, Germany; 'aboratoire d'Hématologie \\ Moléculaire et Cellulaire, Institut Pasteur de Tunis, Université de Tunis-El Manar, Tunisia
}

\section{Key Words}

Phosphatidylserine $\cdot$ Cell volume $•$ Eryptosis $•$ Oxidative stress $\bullet$ Calcium

\begin{abstract}
Background/Aims: Narasin, an ionophore used for the treatment of coccidiosis, has been shown to foster apoptosis of tumor cells. In analogy to apoptosis of nucleated cells, erythrocytes may enter eryptosis, the suicidal erythrocyte death characterized by cell shrinkage and cell membrane scrambling with phosphatidylserine translocation to the erythrocyte surface. Eryptosis may be triggered by $\mathrm{Ca}^{2+}$ entry with subsequent increase of cytosolic $\mathrm{Ca}^{2+}$ activity $\left(\left[\mathrm{Ca}^{2+}\right]_{\mathrm{i}}\right)$, and by ceramide. The present study explored, whether and how narasin induces eryptosis. Methods: Flow cytometry was employed to estimate phosphatidylserine exposure at the cell surface from annexin-V-binding, cell volume from forward scatter, $\left[\mathrm{Ca}^{2+}\right]_{i}$ from Fluo3-fluorescence, and ceramide abundance utilizing specific antibodies. Results: A 48 hours exposure of human erythrocytes to narasin $(10$ and $25 \mathrm{ng} / \mathrm{ml})$ significantly increased the percentage of annexin-V-binding cells. Forward scatter was decreased by $1 \mathrm{ng} / \mathrm{ml}$ narasin but not by higher narasin concentrations (10 and $25 \mathrm{ng} / \mathrm{ml}$ ). Narasin significantly increased Fluo3-fluorescence (10 and $25 \mathrm{ng} / \mathrm{ml}$ ) and slightly, but significantly increased ceramide abundance $(25 \mathrm{ng} / \mathrm{ml})$. The effect of narasin on annexin-V-binding was significantly blunted, but not abolished by removal of extracellular $\mathrm{Ca}^{2+}$. Conclusions: Narasin triggers phospholipid scrambling of the erythrocyte cell membrane, an effect paralleled and partially dependent on $\mathrm{Ca}^{2+}$ entry. Narasin further leads to cell shrinkage and slight increase of ceramide abundance.

(C) 2015 The Author(s)

Published by S. Karger AG, Basel
\end{abstract}

\section{Introduction}

Narasin, a cationic ionophore [1] with antimicrobial activity [2-5] is fed to ruminant animals to improve feed efficiency $[6,7]$. It may accumulate in tissues of edible animals $[8,9]$. It is effective by permeabilizing cell membranes thus dissipating ion gradients of susceptible bacteria [6]. Narasin has been shown to inhibit NF- $\kappa B$ signaling [10]. Narasin fosters apoptosis of tumor cells [11] and has thus been considered for the therapy of malignancy [11].

Prof. Dr. Florian Lang

KARGER 125
Physiologisches Institut der Universität Tübingen

Gmelinstr. 5, D-72076 Tübingen (Germany)

Tel: +49 707129 72194, Fax: +49 707129 5618, E-Mail florian.lang@uni-tuebingen.de 


\section{Cellular Physiology Cell Physiol Biochem 2015;37:1807-1816 \begin{tabular}{l|l|l|l|l}
\hline DOI: 10.1159/000438543 & $\begin{array}{l}\text { () 2015 The Author(s). Published by S. Karger AG, Basel } \\
\text { www.karger.com/cpb }\end{array}$
\end{tabular} \\ Bouguerra et al.: Narasin-Induced Eryptosis}

In analogy to apoptosis of nucleated cells, erythrocytes may enter eryptosis [12], the suicidal death of erythrocytes characterized by cell shrinkage [13] and cell membrane scrambling with phosphatidylserine translocation to the cell surface [12]. Eryptosis could be triggered by $\mathrm{Ca}^{2+}$ entry with increase of cytosolic $\mathrm{Ca}^{2+}$ activity $\left(\left[\mathrm{Ca}^{2+}\right]_{\mathrm{i}}\right)$. Stimulators of eryptosis further include ceramide [14], energy depletion [12], activated caspases [12, 15, 16], stimulated activity of casein kinase $1 \alpha$ [17], Janus-activated kinase JAK3 [18], protein kinase C [12], and p38 kinase [12, 19], as well as impaired activity of AMP activated kinase AMPK [12], cGMP-dependent protein kinase [12], PAK2 kinase [12], and sorafenib/sunitinib sensitive kinases [12]. Eryptosis is stimulated by a wide variety of small molecules [12, 20 45]. Enhanced eryptosis is encountered in several clinical conditions, such as dehydration [33], hyperphosphatemia [43], chronic kidney disease (CKD) [25, 46-48], hemolytic-uremic syndrome [49], diabetes [50], hepatic failure [51], malignancy [12, 52], sepsis [53], sicklecell disease [12, 54], beta-thalassemia [12, 54], Hb-C and G6PD-deficiency [12, 54], as well as Wilsons disease [55].

The present study explored whether and how narasin triggers eryptosis. To this end, human erythrocytes from healthy volunteers were exposed to narasin and phosphatidylserine surface abundance, cell volume as well as $\left[\mathrm{Ca}^{2+}\right]_{i}$ and ceramide abundance determined by flow cytometry.

\section{Materials and Methods}

\section{Erythrocytes, solutions and chemicals}

Fresh Li-Heparin-anticoagulated blood samples were kindly provided by the blood bank of the University of Tübingen. The study is approved by the ethics committee of the University of Tübingen (184/2003 V). The blood was centrifuged at $120 \mathrm{xg}$ for $20 \mathrm{~min}$ at $21^{\circ} \mathrm{C}$ and the platelets and leukocytes-containing supernatant was disposed. Erythrocytes were incubated in vitro at a hematocrit of $0.4 \%$ in Ringer solution containing (in mM) $125 \mathrm{NaCl}, 5 \mathrm{KCl}, 1 \mathrm{MgSO}_{4}, 32 \mathrm{~N}$-2-hydroxyethylpiperazine-N-2-ethanesulfonic acid (HEPES; pH 7.4), 5 glucose, $1 \mathrm{CaCl}_{2}$, at $37^{\circ} \mathrm{C}$ for 48 hours. Where indicated, erythrocytes were exposed to narasin (Sigma Aldrich, Hamburg, Germany) at the indicated concentrations.

\section{Annexin-V-binding and forward scatter}

After incubation under the respective experimental condition, a $150 \mu$ cell suspension was washed in Ringer solution containing $5 \mathrm{mM} \mathrm{CaCl}_{2}$ and then stained with Annexin-V-FITC (1:200 dilution; ImmunoTools, Friesoythe, Germany) in this solution at $37^{\circ} \mathrm{C}$ for $15 \mathrm{~min}$ under protection from light. The annexin $\mathrm{V}$ abundance at the erythrocyte surface was subsequently determined on a FACS Calibur (BD, Heidelberg, Germany). Annexin-V-binding was measured with an excitation wavelength of $488 \mathrm{~nm}$ and an emission wavelength of $530 \mathrm{~nm}$. A marker (M1) was placed to set an arbitrary threshold between annexin-V-binding cells and control cells. The same threshold was used for untreated and narasin treated erythrocytes. A dot plot of forward scatter (FSC) vs. side scatter (SSC) was set to linear scale for both parameters. The threshold of forward scatter was set at the default value of " 52 ".

Intracellular $\mathrm{Ca}^{2+}$

After incubation, erythrocytes were washed in Ringer solution and then loaded with Fluo-3/AM (Biotium, Hayward, USA) in Ringer solution containing $5 \mathrm{mM} \mathrm{CaCl}_{2}$ and $5 \mu \mathrm{M}$ Fluo-3/AM. The cells were incubated at $37^{\circ} \mathrm{C}$ for $30 \mathrm{~min}$ and washed once in Ringer solution containing $5 \mathrm{mM} \mathrm{CaCl}{ }_{2}$. The Fluo-3/AMloaded erythrocytes were resuspended in $200 \mu \mathrm{l}$ Ringer solution and incubated at $37^{\circ} \mathrm{C}$ for $30 \mathrm{~min}$. Then, $\mathrm{Ca}^{2+}$-dependent fluorescence intensity was measured with an excitation wavelength of $488 \mathrm{~nm}$ and an emission wavelength of $530 \mathrm{~nm}$ on a FACS Calibur.

\section{Determination of ceramide formation}

For the determination of ceramide, a monoclonal antibody-based assay was used. After incubation, cells were stained for 1 hour at $37^{\circ} \mathrm{C}$ with $1 \mu \mathrm{g} / \mathrm{ml}$ anti ceramide antibody (clone MID 15B4, Alexis, Grünberg, Germany) in PBS containing $0.1 \%$ bovine serum albumin (BSA) at a dilution of 1:10. The samples were 


\section{Cellular Physiology Cell Physiol Biochem 2015;37:1807-1816 \\ and Biochemistry Published online: November 13, 2015 $\begin{aligned} & \text { (c) } 2015 \text { The Author(s). Published by S. Karger AG, Basel } \\ & \text { www.karger.com/cpb }\end{aligned}$ \\ Bouguerra et al.: Narasin-Induced Eryptosis}

washed twice with PBS-BSA. Subsequently, the cells were stained for 30 minutes with polyclonal fluorescein isothiocyanate (FITC) conjugated goat anti-mouse IgG and IgM specific antibody (Pharmingen, Hamburg, Germany) diluted 1:50 in PBS-BSA. Unbound secondary antibody was removed by repeated washing with PBS-BSA. The samples were then analyzed by flow cytometric analysis with an excitation wavelength of 488 $\mathrm{nm}$ and an emission wavelength of $530 \mathrm{~nm}$.

\section{Statistics}

Data are expressed as arithmetic means \pm SEM. As indicated in the figure legends, statistical analysis was made using ANOVA with Tukey's test as post-test and $t$ test as appropriate. $\mathrm{n}$ denotes the number of different erythrocyte specimens studied. Since different erythrocyte specimens used in distinct experiments are differently susceptible to triggers of eryptosis, the same erythrocyte specimens have been used for control and experimental conditions.

\section{Results}

The present study explored whether narasin is able to trigger eryptosis, the suicidal erythrocyte death characterized by cell shrinkage and cell membrane scrambling with phosphatidylserine translocation to the cell surface. Annexin-V-binding, as determined by flow cytometry, was taken as a measure of phosphatidylserine abundance at the erythrocyte surface. The erythrocytes were analysed following incubation for 48 hours in Ringer solution without or with narasin $(1-25 \mathrm{ng} / \mathrm{ml})$. As illustrated in Fig. 1, a 48 hours exposure to narasin increased the percentage of phosphatidylserine exposing erythrocytes, an effect reaching statistical significance at $10 \mathrm{ng} / \mathrm{ml}$ narasin concentration.

Forward scatter, as determined utilizing flow cytometry, was taken as a measure of erythrocyte volume. Again, measurements were made following a 48 hours incubation in Ringer solution without or with narasin $(1-25 \mathrm{ng} / \mathrm{ml})$. As shown in Fig. 2, low concentrations of narasin $(1 \mathrm{ng} / \mathrm{ml})$ significantly decreased erythrocyte forward scatter. However, forward

Fig. 1. Effect of narasin on phosphatidylserine exposure. A. Original histogram of annexin-Vbinding of erythrocytes following exposure for 48 hours to Ringer solution without (grey area) and with (black line) presence of $25 \mathrm{ng} / \mathrm{ml}$ narasin. B. Arithmetic means \pm SEM $(n=13)$ of erythrocyte annexin-V-binding (black bars) following incubation for 48 hours to Ringer solution without (white bar) or with (black bars) presence of narasin $(1-25 \mathrm{ng} /$ $\mathrm{ml}$ ). For comparison, the effect of the solvent ethanol is shown (grey bar). ${ }^{* *}(P<0.01),{ }^{* * *}(P<0.001)$ indicate significant difference from the absence of narasin (ANOVA).




Fig. 2. Effect of narasin on erythrocyte forward scatter. A. Original histogram of forward scatter of erythrocytes following exposure for 48 hours to Ringer solution without (grey area) and with (black line) presence of $1 \mathrm{ng} / \mathrm{ml}$ narasin. B. Arithmetic means \pm SEM $(n=13)$ of the erythrocyte forward scatter (FSC) following incubation for 48 hours to Ringer solution without (white bar) or with (black bars) presence of narasin $(1-25 \mathrm{ng} / \mathrm{ml})$. For comparison, the effect of the solvent ethanol is shown (grey bar). ${ }^{* * *}(P<0.001)$ indicates significant difference from the absence of narasin (ANOVA).

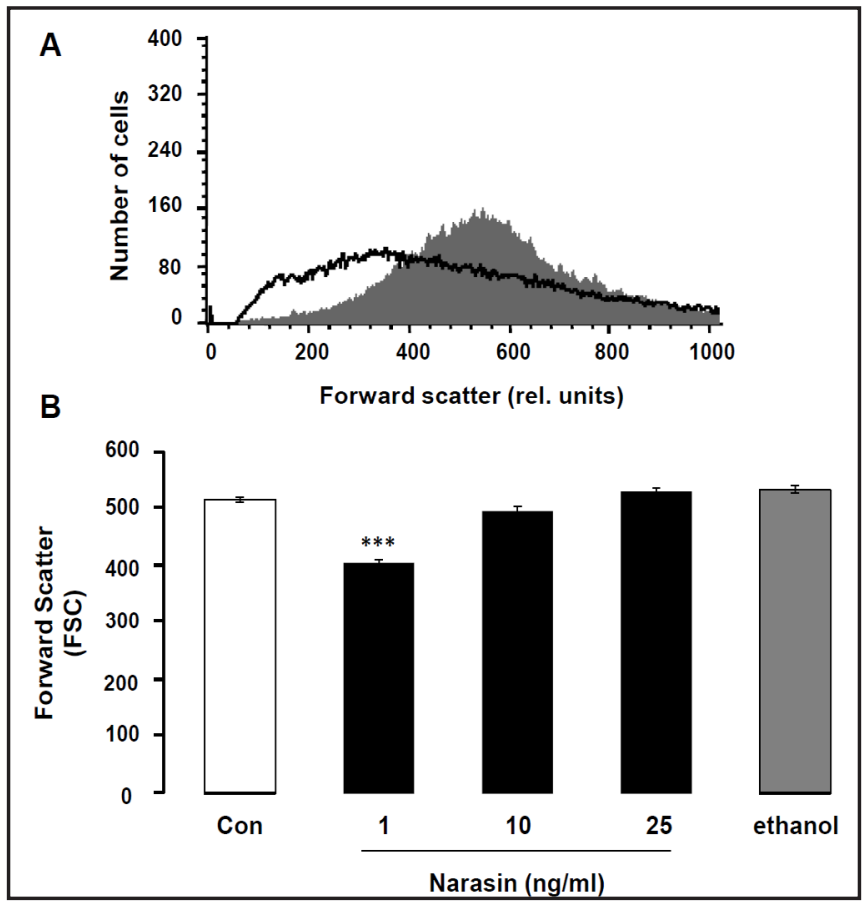

Fig. 3. Effect of narasin on erythrocyte $\mathrm{Ca}^{2+}$ activity. A. Original histogram of Fluo3 fluorescence in erythrocytes following exposure for 48 hours to Ringer solution without (grey area) and with (black line) presence of $25 \mathrm{ng} / \mathrm{ml}$ narasin. B. Arithmetic means \pm SEM $(\mathrm{n}=$ 13) of the Fluo3 fluorescence (arbitrary units) in erythrocytes exposed for 48 hours to Ringer solution without (white bar) or with (black bars) presence of narasin $(1-25 \mathrm{ng} / \mathrm{ml})$. For comparison, the effect of the solvent ethanol is shown (grey bar). ${ }^{* * *}(P<0.001)$ indicates significant difference from the absence of narasin (ANOVA).

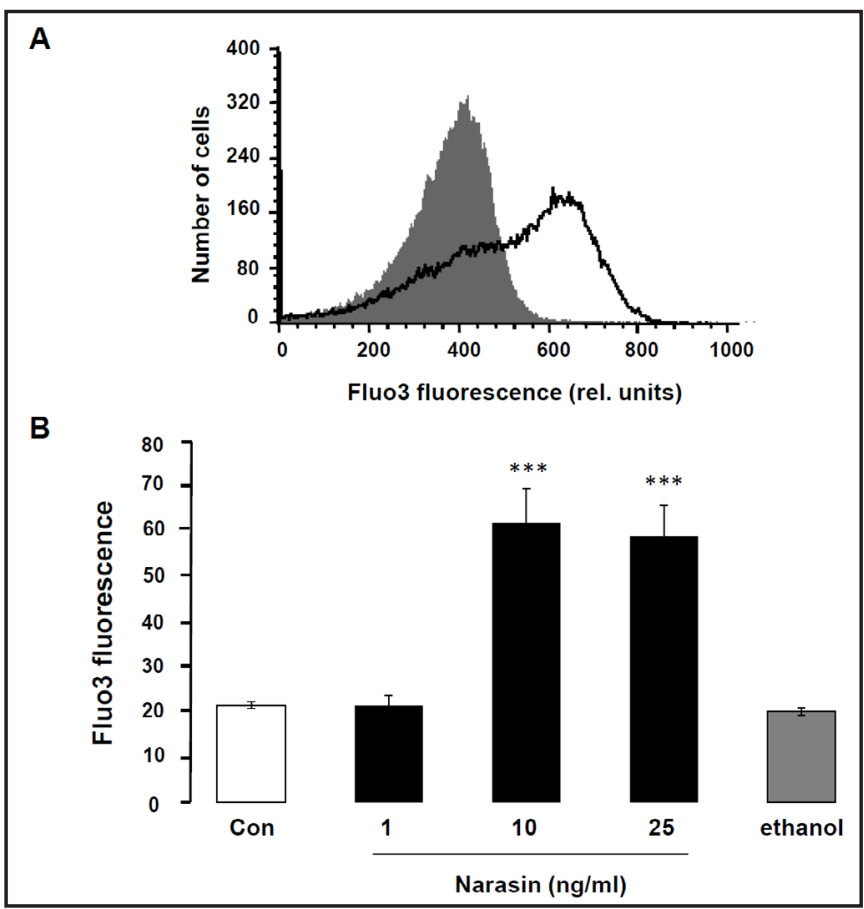

scatter was not significantly modified by higher narasin concentrations (10 and $25 \mathrm{ng} / \mathrm{ml}$ ). Thus, narasin exerted a dual effect on erythrocyte volume.

Fluo3 fluorescence was determined in order to estimate cytosolic $\mathrm{Ca}^{2+}$ activity $\left(\left[\mathrm{Ca}^{2+}\right]_{\mathrm{i}}\right)$. As illustrated in Fig. 3, a 48 hours exposure to 10 or $25 \mathrm{ng} / \mathrm{ml}$ narasin was followed by a significant increase of Fluo3 fluorescence, an observation pointing to an increase of $\left[\mathrm{Ca}^{2+}\right]_{\mathrm{i}}$ following narasin exposure.

In order to test whether the narasin-induced translocation of phosphatidylserine required entry of extracellular $\mathrm{Ca}^{2+}$, erythrocytes were incubated for 48 hours in the absence or presence of $25 \mathrm{ng} / \mathrm{ml}$ narasin in the presence or nominal absence of extracellular $\mathrm{Ca}^{2+}$. As illustrated in Fig. 4, removal of extracellular $\mathrm{Ca}^{2+}$ significantly blunted the effect of narasin 


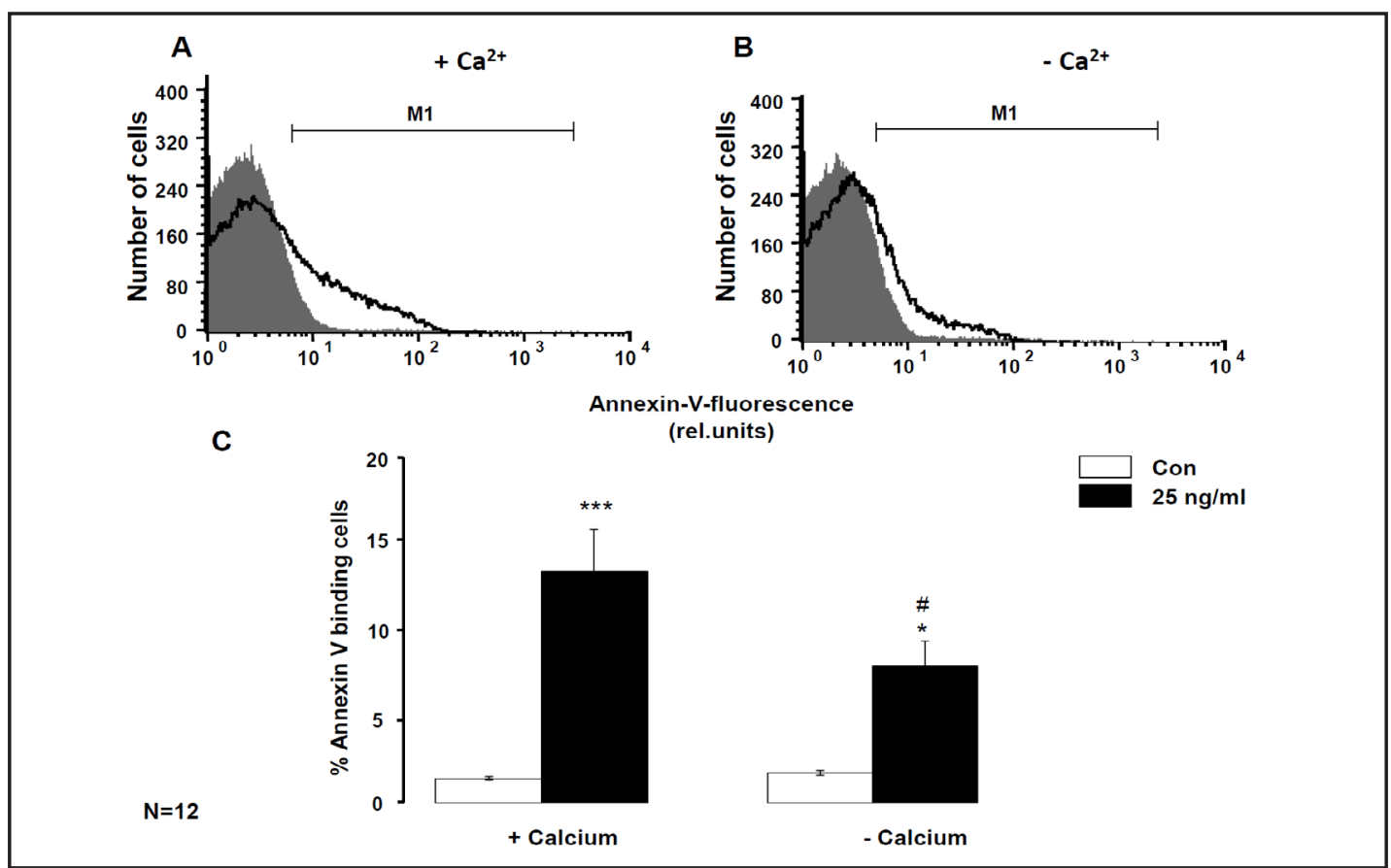

Fig. 4. $\mathrm{Ca}^{2+}$ sensitivity of narasin -induced phosphatidylserine exposure. A,B. Original histograms of annexin-V-binding of erythrocytes following exposure for 48 hours to Ringer solution without (grey area) and with (black line) presence of $25 \mathrm{ng} / \mathrm{ml}$ narasin in the presence (A) and absence (B) of extracellular $\mathrm{Ca}^{2+}$. C. Arithmetic means \pm SEM $(n=12)$ of annexin-V-binding of erythrocytes after a 48 hours treatment with Ringer solution without (white bars) or with (black bars) $25 \mathrm{ng} / \mathrm{ml}$ narasin in the presence (left bars, $+\mathrm{Ca}^{2+}$ ) and absence (right bars, $\left.-\mathrm{Ca}^{2+}\right)$ of $\mathrm{Ca}^{2+} . *(P<0.05)$ and ${ }^{* * *}(P<0.001)$ indicate significant difference from the absence of narasin, $\#(P<0.05)$ indicates significant difference from the presence of $\mathrm{Ca}^{2+}(\mathrm{ANOVA})$.

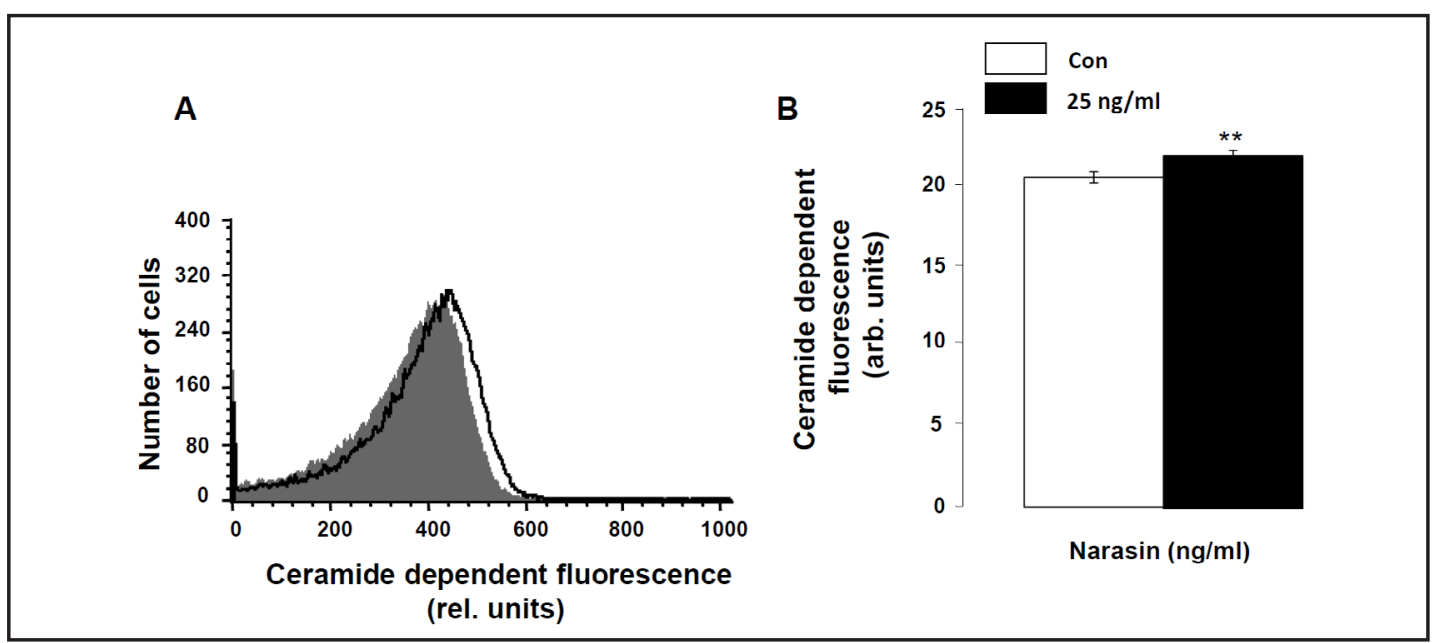

Fig. 5. Effect of narasin on ceramide formation. A. Original histogram of ceramide abundance in erythrocytes following exposure for 48 hours to Ringer solution without (grey area) and with (black line) presence of $25 \mathrm{ng} / \mathrm{ml}$ narasin. B. Arithmetic means \pm SEM $(\mathrm{n}=12)$ of the ceramide abundance (arbitrary units) in erythrocytes exposed for 48 hours to Ringer solution without (white bar) or with (black bar) presence of 25 $\mathrm{ng} / \mathrm{ml}$ narasin. ${ }^{* *}(P<0.01)$ indicates significant difference from the absence of narasin (paired $t$ test).

on annexin-V-binding. However, narasin significantly increased the percentage of annexinV-binding erythrocytes even in the absence of extracellular $\mathrm{Ca}^{2+}$. Thus, narasin-induced cell membrane scrambling was partially but not completely due to entry of extracellular $\mathrm{Ca}^{2+}$. 


\section{Cellular Physiology Cell Physiol Biochem 2015;37:1807-1816 \\ \begin{tabular}{l|l|l|l|l|l}
\hline DOI: 10.1159/000438543 & $\begin{array}{l}\text { C) } 2015 \text { The Author(s). Published by S. Karger AG, Basel } \\
\text { www.karger.com/cpb }\end{array}$
\end{tabular} \\ Bouguerra et al.: Narasin-Induced Eryptosis}

In search for an additional mechanism triggering eryptosis, ceramide abundance at the erythrocyte surface was quantified utilizing specific antibodies. As illustrated in Fig. 5, a 48 hours exposure to narasin $(25 \mathrm{ng} / \mathrm{ml})$ slightly but significantly increased the ceramide abundance at the erythrocyte surface.

\section{Discussion}

The present study reveals a novel effect of narasin, i.e. the stimulation of suicidal erythrocyte death or eryptosis. Exposure of human erythrocytes to narasin results in decrease of forward scatter reflecting cell shrinkage and to increase of annexin-V-binding reflecting cell membrane scrambling with phosphatidylserine translocation to the erythrocyte surface. The concentrations required for the observed effect are within the range of plasma concentrations of treated poultry [56].

The effect of narasin on cell membrane scrambling was paralleled by and in part due to increase of cytosolic $\mathrm{Ca}^{2+}$ activity $\left(\left[\mathrm{Ca}^{2+}\right]_{\mathrm{j}}\right)$. Accordingly, the narasin induced cell membrane scrambling was blunted in the absence of extracellular $\mathrm{Ca}^{2+}$. However, narasin triggered cell membrane scrambling even in the absence of extracellular $\mathrm{Ca}^{2+}$, an observation pointing to involvement of additional mechanisms. Those mechanisms may include ceramide, which is slightly but significantly increased following narasin exposure.

An increase of $\left[\mathrm{Ca}^{2+}\right]_{i}$ is further expected to decrease cell volume due to activation of $\mathrm{Ca}^{2+}$ sensitive $\mathrm{K}^{+}$channels with subsequent cell shrinkage due to $\mathrm{K}^{+}$exit, cell membrane hyperpolarization, $\mathrm{Cl}^{-}$exit and thus cellular loss of $\mathrm{KCl}$ with water [13]. However, a decrease of cell volume was not observed at higher concentrations of narasin. Possibly the ionophore mediated ion entry outweighs the loss of $\mathrm{KCl}$ due to activation of $\mathrm{Ca}^{2+}$ sensitive $\mathrm{K}^{+}$channels.

The physiological function of eryptosis is the clearance of defective erythrocytes from circulating blood prior to hemolysis [12]. Triggering of eryptosis avoids the release of hemoglobin, which would otherwise pass the glomerular filter of the kidney, precipitate in the acidic lumen of renal tubules and thus occlude nephrons [57]. In malaria, eryptosis allows the clearance of Plasmodium infected erythrocytes. Oxidative stress induced by the pathogen activates $\mathrm{Ca}^{2+}$-permeable erythrocyte cation channels in the infected host erythrocyte [12, 58]. Eryptosis and subsequent clearance of infected erythrocytes are accelerated in patients carrying sickle-cell trait, beta-thalassemia-trait, Hb-C and G6PD-deficiency. The accelerated death of infected erythrocytes in those disorders counteracts parasitemia and thus protects against a severe course of malaria [12, 59-61]. The enhanced eryptosis in iron deficiency [62], and following treatment with lead [62], chlorpromazine [63] or NO synthase inhibitors [63] similarly counteracts parasitemia. At least in theory, narasin could similarly enhance the susceptibility of Plasmodium infected erythrocytes to eryptosis.

Excessive eryptosis leads, however, to anemia [12]. Moreover, eryptosis may foster adherence of phosphatidylserine exposing erythrocytes to the vascular wall [64], stimulate blood clotting and trigger thrombosis [65-67]. Excessive eryptosis may thus compromise microcirculation [14, 65, 68-71].

In conclusion, narasin triggers cell membrane scrambling, an effect paralleled by and in part due to increase of cytosolic $\mathrm{Ca}^{2+}$ activity. Low concentrations of narasin further lead to cell shrinkage. Narasin thus triggers eryptosis, the suicidal death of erythrocytes.

\section{Acknowledgements}

The authors acknowledge the meticulous preparation of the manuscript by Tanja Loch. The study was supported by the Deutsche Forschungsgemeinschaft and Open Access Publishing Fund of Tuebingen University. 


\section{Cellular Physiology Cell Physiol Biochem 2015;37:1807-1816

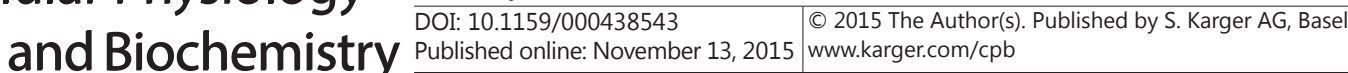 \\ Bouguerra et al.: Narasin-Induced Eryptosis}

\section{Disclosure Statement}

The authors of this manuscript state that they have no conflicts of interest to declare.

\section{References}

1 Riddell FG: Structure, conformation, and mechanism in the membrane transport of alkali metal ions by ionophoric antibiotics. Chirality 2002;14:121-125.

2 Butaye P, Devriese LA, Haesebrouck F: Antimicrobial growth promoters used in animal feed: effects of less well known antibiotics on gram-positive bacteria. Clin Microbiol Rev 2003;16:175-188.

3 Dorne JL, Fernandez-Cruz ML, Bertelsen U, Renshaw DW, Peltonen K, Anadon A, Feil A, Sanders P, Wester P, Fink-Gremmels J: Risk assessment of coccidostatics during feed cross-contamination: animal and human health aspects. Toxicol Appl Pharmacol 2013;270:196-208.

4 Greif G, Harder A, Haberkorn A: Chemotherapeutic approaches to protozoa: Coccidiae--current level of knowledge and outlook. Parasitol Res 2001;87:973-975.

5 Oehme FW, Pickrell JA: An analysis of the chronic oral toxicity of polyether ionophore antibiotics in animals. Vet Hum Toxicol 1999;41:251-257.

6 Callaway TR, Edrington TS, Rychlik JL, Genovese KJ, Poole TL, Jung YS, Bischoff KM, Anderson RC, Nisbet DJ: Ionophores: their use as ruminant growth promotants and impact on food safety. Curr Issues Intest Microbiol 2003;4:43-51.

7 Szkudlarek-Mikho M, Saunders RA, Yap SF, Ngeow YF, Chin KV: Salinomycin, a polyether ionophoric antibiotic, inhibits adipogenesis. Biochem Biophys Res Commun 2012;428:487-493.

8 Burnett TJ, Lombardi K, Rodewald JM, Brunelle SL, MacDougall J, Coleman MR: Determination of narasin and monensin in bovine, swine, and chicken tissues by liquid chromatography with tandem mass spectrometry: first action 2011.24. J AOAC Int 2012;95:959-991.

9 Lombardi KR, Burnett TJ, Brunelle SL, Ulrey WD, Coleman MR: Determination and confirmation of narasin and monensin in chicken, swine, and bovine tissues by LC/MS/MS: Final Action 2011.24. J AOAC Int 2013;96:902-909.

10 Miller SC, Huang R, Sakamuru S, Shukla SJ, Attene-Ramos MS, Shinn P, Van Leer D, Leister W, Austin CP, Xia M: Identification of known drugs that act as inhibitors of NF-kappaB signaling and their mechanism of action. Biochem Pharmacol 2010;79:1272-1280.

11 Yoon MJ, Kang YJ, Kim IY, Kim EH, Lee JA, Lim JH, Kwon TK, Choi KS: Monensin, a polyether ionophore antibiotic, overcomes TRAIL resistance in glioma cells via endoplasmic reticulum stress, DR5 upregulation and c-FLIP downregulation. Carcinogenesis 2013;34:1918-1928.

12 Lang F, Qadri SM: Mechanisms and significance of eryptosis, the suicidal death of erythrocytes. Blood Purif 2012;33:125-130.

13 Lang PA, Kaiser S, Myssina S, Wieder T, Lang F, Huber SM: Role of Ca2+-activated K+ channels in human erythrocyte apoptosis. Am J Physiol Cell Physiol 2003;285:C1553-C1560.

14 Abed M, Towhid ST, Mia S, Pakladok T, Alesutan I, Borst O, Gawaz M, Gulbins E, Lang F: Sphingomyelinaseinduced adhesion of eryptotic erythrocytes to endothelial cells. Am J Physiol Cell Physiol 2012;303:C991999.

15 Lau IP, Chen H, Wang J, Ong HC, Leung KC, Ho HP, Kong SK: In vitro effect of CTAB- and PEG-coated gold nanorods on the induction of eryptosis/erythroptosis in human erythrocytes. Nanotoxicology 2012;6:847856.

16 Maellaro E, Leoncini S, Moretti D, Del Bello B, Tanganelli I, De Felice C, Ciccoli L: Erythrocyte caspase-3 activation and oxidative imbalance in erythrocytes and in plasma of type 2 diabetic patients. Acta Diabetol 2013;50:489-495.

17 Zelenak C, Eberhard M, Jilani K, Qadri SM, Macek B, Lang F: Protein kinase CK1alpha regulates erythrocyte survival. Cell Physiol Biochem 2012;29:171-180.

18 Bhavsar SK, Gu S, Bobbala D, Lang F: Janus kinase 3 is expressed in erythrocytes, phosphorylated upon energy depletion and involved in the regulation of suicidal erythrocyte death. Cell Physiol Biochem 2011;27:547-556. 


\section{Cellular Physiology Cell Physiol Biochem 2015;37:1807-1816

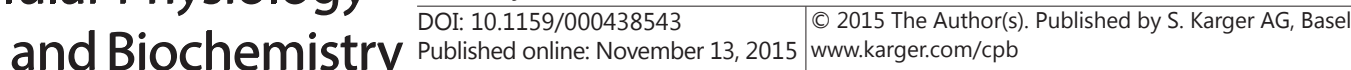 \\ Bouguerra et al.: Narasin-Induced Eryptosis}

19 Gatidis S, Zelenak C, Fajol A, Lang E, Jilani K, Michael D, Qadri SM, Lang F: p38 MAPK activation and function following osmotic shock of erythrocytes. Cell Physiol Biochem 2011;28:1279-1286.

20 Jilani K, Lang F: Carmustine-induced phosphatidylserine translocation in the erythrocyte membrane. Toxins (Basel) 2013;5:703-716.

21 Vota DM, Maltaneri RE, Wenker SD, Nesse AB, Vittori DC: Differential erythropoietin action upon cells induced to eryptosis by different agents. Cell Biochem Biophys 2013;65:145-157.

22 Zappulla D: Environmental stress, erythrocyte dysfunctions, inflammation, and the metabolic syndrome: adaptations to CO2 increases? J Cardiometab Syndr 2008;3:30-34.

23 Lupescu A, Jilani K, Zbidah M, Lang F: Patulin-induced suicidal erythrocyte death. Cell Physiol Biochem 2013;32:291-299.

24 Abed M, Zoubi KA, Theurer M, Lang F: Effect of dermaseptin on erythrocytes. Basic Clin Pharmacol Toxicol 2013;113:347-352.

25 Ahmed MS, Langer H, Abed M, Voelkl J, Lang F: The uremic toxin acrolein promotes suicidal erythrocyte death. Kidney Blood Press Res 2013;37:158-167.

26 Ghashghaeinia M, Cluitmans JC, Toulany M, Saki M, Koberle M, Lang E, Dreischer P, Biedermann T, Duszenko M, Lang F, Bosman GJ, Wieder T: Age Sensitivity of NFkappaB Abundance and Programmed Cell Death in Erythrocytes Induced by NFkappaB Inhibitors. Cell Physiol Biochem 2013;32:801-813.

27 Alzoubi K, Honisch S, Abed M, Lang F: Triggering of Suicidal Erythrocyte Death by Penta-O-galloyl-beta-dglucose. Toxins (Basel) 2014;6:54-65.

28 Jilani K, Enkel S, Bissinger R, Almilaji A, Abed M, Lang F: Fluoxetine induced suicidal erythrocyte death. Toxins (Basel) 2013;5:1230-1243.

29 Lupescu A, Bissinger R, Jilani K, Lang F: Triggering of suicidal erythrocyte death by celecoxib. Toxins (Basel) 2013;5:1543-1554.

30 Arnold M, Lang E, Modicano P, Bissinger R, Faggio C, Abed M, Lang F: Effect of nitazoxanide on erythrocytes. Basic Clin Pharmacol Toxicol 2014;114:421-426.

31 Oswald G, Alzoubi K, Abed M, Lang F: Stimulation of suicidal erythrocyte death by ribavirin. Basic Clin Pharmacol Toxicol 2014;114:311-317.

32 Lupescu A, Bissinger R, Herrmann T, Oswald G, Jilani K, Lang F: Induction of suicidal erythrocyte death by novobiocin. Cell Physiol Biochem 2014;33:670-680.

33 Abed M, Feger M, Alzoubi K, Pakladok T, Frauenfeld L, Geiger C, Towhid ST, Lang F: Sensitization of erythrocytes to suicidal erythrocyte death following water deprivation. Kidney Blood Press Res 2013;37:567-578.

34 Alzoubi K, Calabròa S, Bissinger R, Abed M, Faggio C, Lang F: Stimulation of Suicidal Erythrocyte Death by Artesunate. Cell Physiol Biochem 2014;34:2232-2244.

35 Arnold M, Bissinger R, Lang F: Mitoxantrone-induced suicidal erythrocyte death. Cell Physiol Biochem 2014;34:1756-1767.

36 Bissinger R, Fischer S, Jilani K, Lang F: Stimulation of Erythrocyte Death by Phloretin. Cell Physiol Biochem 2014;34:2256-2265.

37 Bissinger R, Lupescu A, Zelenak C, Jilani K, Lang F: Stimulation of eryptosis by cryptotanshinone. Cell Physiol Biochem 2014;34:432-442.

38 Bissinger R, Modicano P, Frauenfeld L, Lang E, Jacobi J, Faggio C, Lang F: Estramustine-induced suicidal erythrocyte death. Cell Physiol Biochem 2013;32:1426-1436.

39 Jacobi J, Lang E, Bissinger R, Frauenfeld L, Modicano P, Faggio C, Abed M, Lang F: Stimulation of erythrocyte cell membrane scrambling by mitotane. Cell Physiol Biochem 2014;33:1516-1526.

40 Lupescu A, Bissinger R, Warsi J, Jilani K, Lang F: Stimulation of erythrocyte cell membrane scrambling by gedunin. Cell Physiol Biochem 2014;33:1838-1848.

41 Malik A, Bissinger R, Calabro S, Faggio C, Jilani K, Lang F: Aristolochic Acid Induced Suicidal Erythrocyte Death. Kidney Blood Press Res 2014;39:408-419.

42 Tesoriere L, Attanzio A, Allegra M, Cilla A, Gentile C, Livrea MA: Oxysterol mixture in hypercholesterolemiarelevant proportion causes oxidative stress-dependent eryptosis. Cell Physiol Biochem 2014;34:10751089.

43 Voelkl J, Alzoubi K, Mamar AK, Ahmed MS, Abed M, Lang F: Stimulation of suicidal erythrocyte death by increased extracellular phosphate concentrations. Kidney Blood Press Res 2013;38:42-51. 


\section{Cellular Physiology Cell Physiol Biochem 2015;37:1807-1816

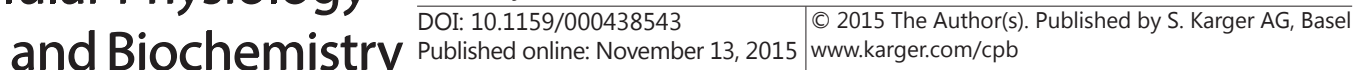 \\ Bouguerra et al.: Narasin-Induced Eryptosis}

44 Zhang R, Xiang Y, Ran Q, Deng X, Xiao Y, Xiang L, Li Z: Involvement of calcium, reactive oxygen species, and ATP in hexavalent chromium-induced damage in red blood cells. Cell Physiol Biochem 2014;34:1780-1791.

45 Pagano M, Faggio C: The use of erythrocyte fragility to assess xenobiotic cytotoxicity. Cell Biochem Funct 2015;33:351-355.

46 Abed M, Artunc F, Alzoubi K, Honisch S, Baumann D, Foller M, Lang F: Suicidal erythrocyte death in endstage renal disease. J Mol Med (Berl) 2014;92:871-879.

47 Polak-Jonkisz D, Purzyc L: Ca(2+) influx versus efflux during eryptosis in uremic erythrocytes. Blood Purif 2012;34:209-210; author reply 210.

48 Calderon-Salinas JV, Munoz-Reyes EG, Guerrero-Romero JF, Rodriguez-Moran M, Bracho-Riquelme RL, Carrera-Gracia MA, Quintanar-Escorza MA: Eryptosis and oxidative damage in type 2 diabetic mellitus patients with chronic kidney disease. Mol Cell Biochem 2011;357:171-179.

49 Lang PA, Beringer O, Nicolay JP, Amon O, Kempe DS, Hermle T, Attanasio P, Akel A, Schafer R, Friedrich B, Risler T, Baur M, Olbricht CJ, Zimmerhackl LB, Zipfel PF, Wieder T, Lang F: Suicidal death of erythrocytes in recurrent hemolytic uremic syndrome. J Mol Med (Berl) 2006;84:378-388.

50 Nicolay JP, Schneider J, Niemoeller OM, Artunc F, Portero-Otin M, Haik G, Jr., Thornalley PJ, Schleicher E, Wieder T, Lang F: Stimulation of suicidal erythrocyte death by methylglyoxal. Cell Physiol Biochem 2006;18:223-232.

51 Lang E, Gatidis S, Freise NF, Bock H, Kubitz R, Lauermann C, Orth HM, Klindt C, Schuier M, Keitel V, Reich M, Liu G, Schmidt S, Xu HC, Qadri SM, Herebian D, Pandyra AA, Mayatepek E, Gulbins E, Lang F, Haussinger D, Lang KS, Foller M, Lang PA: Conjugated bilirubin triggers anemia by inducing erythrocyte death. Hepatology 2015;61:275-284.

52 Qadri SM, Mahmud H, Lang E, Gu S, Bobbala D, Zelenak C, Jilani K, Siegfried A, Foller M, Lang F: Enhanced suicidal erythrocyte death in mice carrying a loss-of-function mutation of the adenomatous polyposis coli gene. J Cell Mol Med 2012;16:1085-1093.

53 Kempe DS, Akel A, Lang PA, Hermle T, Biswas R, Muresanu J, Friedrich B, Dreischer P, Wolz C, Schumacher U, Peschel A, Gotz F, Doring G, Wieder T, Gulbins E, Lang F: Suicidal erythrocyte death in sepsis. J Mol Med (Berl) 2007;85:273-281.

54 Lang KS, Roll B, Myssina S, Schittenhelm M, Scheel-Walter HG, Kanz L, Fritz J, Lang F, Huber SM, Wieder T: Enhanced erythrocyte apoptosis in sickle cell anemia, thalassemia and glucose-6-phosphate dehydrogenase deficiency. Cell Physiol Biochem 2002;12:365-372.

55 Lang PA, Schenck M, Nicolay JP, Becker JU, Kempe DS, Lupescu A, Koka S, Eisele K, Klarl BA, Rubben H, Schmid KW, Mann K, Hildenbrand S, Hefter H, Huber SM, Wieder T, Erhardt A, Haussinger D, Gulbins E, Lang F: Liver cell death and anemia in Wilson disease involve acid sphingomyelinase and ceramide. Nat Med 2007;13:164-170.

56 Peippo P, Hagren V, Lovgren T, Tuomola M: Rapid time-resolved fluoroimmunoassay for the screening of narasin and salinomycin residues in poultry and eggs. J Agric Food Chem 2004;52:1824-1828.

57 Harrison HE, Bunting H, Ordway NK, Albrink WS: The Pathogenesis of the Renal Injury Produced in the Dog by Hemoglobin or Methemoglobin. J Exp Med 1947;86:339-356.

58 Kirk K: Membrane transport in the malaria-infected erythrocyte. Physiol Rev 2001;81:495-537.

59 Ayi K, Giribaldi G, Skorokhod A, Schwarzer E, Prendergast PT, Arese P: 16alpha-bromoepiandrosterone, an antimalarial analogue of the hormone dehydroepiandrosterone, enhances phagocytosis of ring stage parasitized erythrocytes: a novel mechanism for antimalarial activity. Antimicrob Agents Chemother 2002;46:3180-3184.

60 Ayi K, Turrini F, Piga A, Arese P: Enhanced phagocytosis of ring-parasitized mutant erythrocytes: a common mechanism that may explain protection against falciparum malaria in sickle trait and beta-thalassemia trait. Blood 2004;104:3364-3371.

61 Cappadoro M, Giribaldi G, O'Brien E, Turrini F, Mannu F, Ulliers D, Simula G, Luzzatto L, Arese P: Early phagocytosis of glucose-6-phosphate dehydrogenase (G6PD)-deficient erythrocytes parasitized by Plasmodium falciparum may explain malaria protection in G6PD deficiency. Blood 1998;92:2527-2534.

62 Koka S, Huber SM, Boini KM, Lang C, Foller M, Lang F: Lead decreases parasitemia and enhances survival of Plasmodium berghei-infected mice. Biochem Biophys Res Commun 2007;363:484-489.

63 Koka S, Lang C, Niemoeller OM, Boini KM, Nicolay JP, Huber SM, Lang F: Influence of NO synthase inhibitor L-NAME on parasitemia and survival of Plasmodium berghei infected mice. Cell Physiol Biochem 2008;21:481-488. 


\section{Cellular Physiology Cell Physiol Biochem 2015;37:1807-1816 \begin{tabular}{ll|l|l|l} 
DOI: 10.1159/000438543 & O 2015 The Author(s). Published by S. Karger AG, Basel \\
www.karger.com/cpb
\end{tabular} \\ Bouguerra et al.: Narasin-Induced Eryptosis}

64 Borst O, Abed M, Alesutan I, Towhid ST, Qadri SM, Foller M, Gawaz M, Lang F: Dynamic adhesion of eryptotic erythrocytes to endothelial cells via CXCL16/SR-PSOX. Am J Physiol Cell Physiol 2012;302:C644-C651.

65 Andrews DA, Low PS: Role of red blood cells in thrombosis. Curr Opin Hematol 1999;6:76-82.

66 Chung SM, Bae ON, Lim KM, Noh JY, Lee MY, Jung YS, Chung JH: Lysophosphatidic acid induces thrombogenic activity through phosphatidylserine exposure and procoagulant microvesicle generation in human erythrocytes. Arterioscler Thromb Vasc Biol 2007;27:414-421.

67 Zwaal RF, Comfurius P, Bevers EM: Surface exposure of phosphatidylserine in pathological cells. Cell Mol Life Sci 2005;62:971-988.

68 Closse C, Dachary-Prigent J, Boisseau MR: Phosphatidylserine-related adhesion of human erythrocytes to vascular endothelium. Br J Haematol 1999;107:300-302.

69 Gallagher PG, Chang SH, Rettig MP, Neely JE, Hillery CA, Smith BD, Low PS: Altered erythrocyte endothelial adherence and membrane phospholipid asymmetry in hereditary hydrocytosis. Blood 2003;101:46254627.

70 Pandolfi A, Di Pietro N, Sirolli V, Giardinelli A, Di Silvestre S, Amoroso L, Di Tomo P, Capani F, Consoli A, Bonomini M: Mechanisms of uremic erythrocyte-induced adhesion of human monocytes to cultured endothelial cells. J Cell Physiol 2007;213:699-709.

71 Wood BL, Gibson DF, Tait JF: Increased erythrocyte phosphatidylserine exposure in sickle cell disease: flowcytometric measurement and clinical associations. Blood 1996;88:1873-1880. 